\title{
Award-Winning Organizations: How Outstanding Organizations Manage the Registration, Access and use of the Knowledge of Employees
}

\author{
Ragna Kemp Haraldsdóttir \\ University of Iceland, Reykjavik, Iceland \\ rh@hi.is \\ DOI: 10.34190/EJKM.18.02.001
}

\begin{abstract}
Organizations have managed information regarding knowledge of employees using various processes such as knowledge mapping, network analysis, codification and personalization. Some of these organizations have been chosen to receive awards for their outstanding performance, for instance for their finest use of knowledge. This paper examines how knowledge award-winning organizations distinguished themselves from other organizations, when it came to the registration, access and use of the knowledge of employees. The aim was to provide an understanding of how these organizations supported personal knowledge registration, and whether winning an award entailed a more comprehensive overview of the knowledge residing in employees. Whether the organizations benefitted financially from the registration process was also examined. This was a qualitative research. It was a multiple-case study, covering 18 organizations in Iceland, of which six had received the Knowledge Company of the Year award. A total of 35 semi-structured interviews were conducted and six award-winning verdicts analysed. A conceptual model was used to clarify the results. The findings indicate that the award-winning organizations received the award for outstanding success. Still, little emphasis was put on the management of the personal knowledge of employees. Interviewees experienced adversity regarding costs, time, limited access and use of personal knowledge. Most interviewees claimed that the registration of knowledge had a financial gain but found it difficult to measure and hard to confirm.
\end{abstract}

Keywords: Personal knowledge, Registration, Knowledge award, Intellectual assets, Financial benefits

\section{Introduction}

In an organization of 200-300 employees, it is possible for people to know one another "well enough to have a reliable grasp of collective organizational knowledge", but beyond this size, it becomes impossible (Davenport and Prusak, 1998, p. 17-18). Organizations are becoming more interested in assessing, managing and developing their intellectual assets, the knowledge of their employees (Buenechea-Elberdin, Sáenz and Kianto, 2018). In order to enable employees to store the knowledge they have, and to make it available for wider use, some organizations have implemented knowledge management systems (KMS) (Sutanto and Jiang, 2013; Kavanagh and Johnson, 2017). Despite the notion that information, for instance on intellectual assets, is considered valuable (Sundquist and Svärd, 2016), few organizations have a way to systematically track the skills of their employees or to estimate what skills they lack (Hesse, 2017; Haraldsdottir et al, 2018). Former studies have indicated that the registration of the knowledge of employees is lacking in organizations (Haraldsdottir and Gunnlaugsdottir, 2018; Grimsdottir and Edvardsson, 2018).

At times it happens that the knowledge or expertise needed for a project, already exists within the organization without the employees being aware of it (O'Dell and Grayson, 1998). It so happened that this lack of overview of the knowledge of employees was somewhat affirmed years ago at a former workplace of the author of this paper. A training manager had called looking for a specific financial expert to conduct an in-house training programme. After telling the training manager that the person she was looking for was an employee in her organization, the reply was: "Really, does he work for us, oh please don't tell anyone I asked you!"

New aspects of knowledge sharing, and reuse have entered the information management literature. The term personal knowledge registration and the abbreviation PKR were created by the author of this paper to explain the topic of this research and to conceptualize the specific elements that constitute the registration, access and use of personal knowledge. PKR is a system of concepts, methods and processes that can be implemented in different information systems. PKR can also be defined as a social knowledge system, a community of knowledge, and a directory to the education, training and experience of employees, residing within an organization (Haraldsdottir, 2019). The abbreviation PKR is thus used to denote both the registration process and occasionally the registry itself. 
Awards are one popular way of acknowledging extraordinary efforts within certain domains. Thus, awards may be one proxy for achievement within knowledge management (KM), for instance on PKR. This paper examines the award-verdicts of the recipients of the Knowledge Company of the Year award. This was done by studying whether winning a knowledge award entailed a comprehensive overview of employees' knowledge residing within an organization. Also, by studying how these organizations were managing possible challenges regarding registration, access and use of employees' knowledge. Whether the organizations experienced a financial gain through the registration of personal knowledge was also examined. The research questions are the following:

1. In what manner, if any, do knowledge award-winning organizations practice PKR?

2. What financial benefits do award-winning organizations reap from practicing PKR?

The paper is organized into seven sections. Section two and three examines relevant studies. Methodology is presented in section four. Section five contains the key findings. Discussions and summary are covered in section six and conclusion in section seven.

\section{The sharing of personal knowledge using PKR}

Knowledge has been defined in a variety of ways, usually by making a distinction between knowledge and information. Most definitions share the notion of knowledge involving the "interaction with the human" (Fernie et al., 2003, p. 178) and processing the reality at hand. Making judgments is the ability of the individual. It can, therefore, be claimed that all knowledge is personal, i.e., bound to the way the individual places meaning and interprets information (Hwang, Lin and Shin, 2018; Pauleen, 2009).

While the management of personal knowledge concerns increasing individual effectiveness in work environments and the knowledge of society for the benefit of the individual, PKR has the possibility to create a social community of personal knowledge, as described by Sigala and Chalkiti (2014). Their study of how web 2.0 enhanced and transformed KM practices in Greek tourism revealed that knowledge sharing was a process by which an individual "imparts his or her expertise, insight or understanding to another individual". The knowledge seeker, or recipient, may draw on the knowledge of the knowledge owner by "[using] the knowledge to perform his or her task(s) in a better way" (2014, p. 801). Christensen and Pedersen (2018) studied how intraorganizational proximity influenced the frequency of knowledge transfer and supported the notion that social relationships had a positive effect on the transfer of knowledge. In their study of trust over ties, Evans, Frissen and Choo (2019) found that frequent interactions and trust provide opportunities to share information that lead to the receipt of useful knowledge, while sufficient time allows relationships to develop. The results of Christensen and Pedersen (2018, p. 1799), Sigala and Chalkiti (2014) and Evans, Frissen and Choo 2019) "echo what practitioners often claim [to be] the main barriers of knowledge sharing: the time and resources required engaging in knowledge sharing activities".

PKR can be described as a platform that facilitates the interaction of individuals who, after having used the platform, can share their knowledge directly. A platform has been defined as "different mechanisms or technological vehicles for connecting people and information" (McFarland and Ployhart, 2015, p. 1654). PKR has the potential to facilitate knowledge sharing. Since PKR consists of information on the personal knowledge of employees while employed, registered information, if regularly updated, remains searchable and applicable.

To further explain PKR, a theoretical model, portraying PKR amid three interdisciplinary fields, was created to describe the theoretical and contextual position of PKR, see Figure 1. 


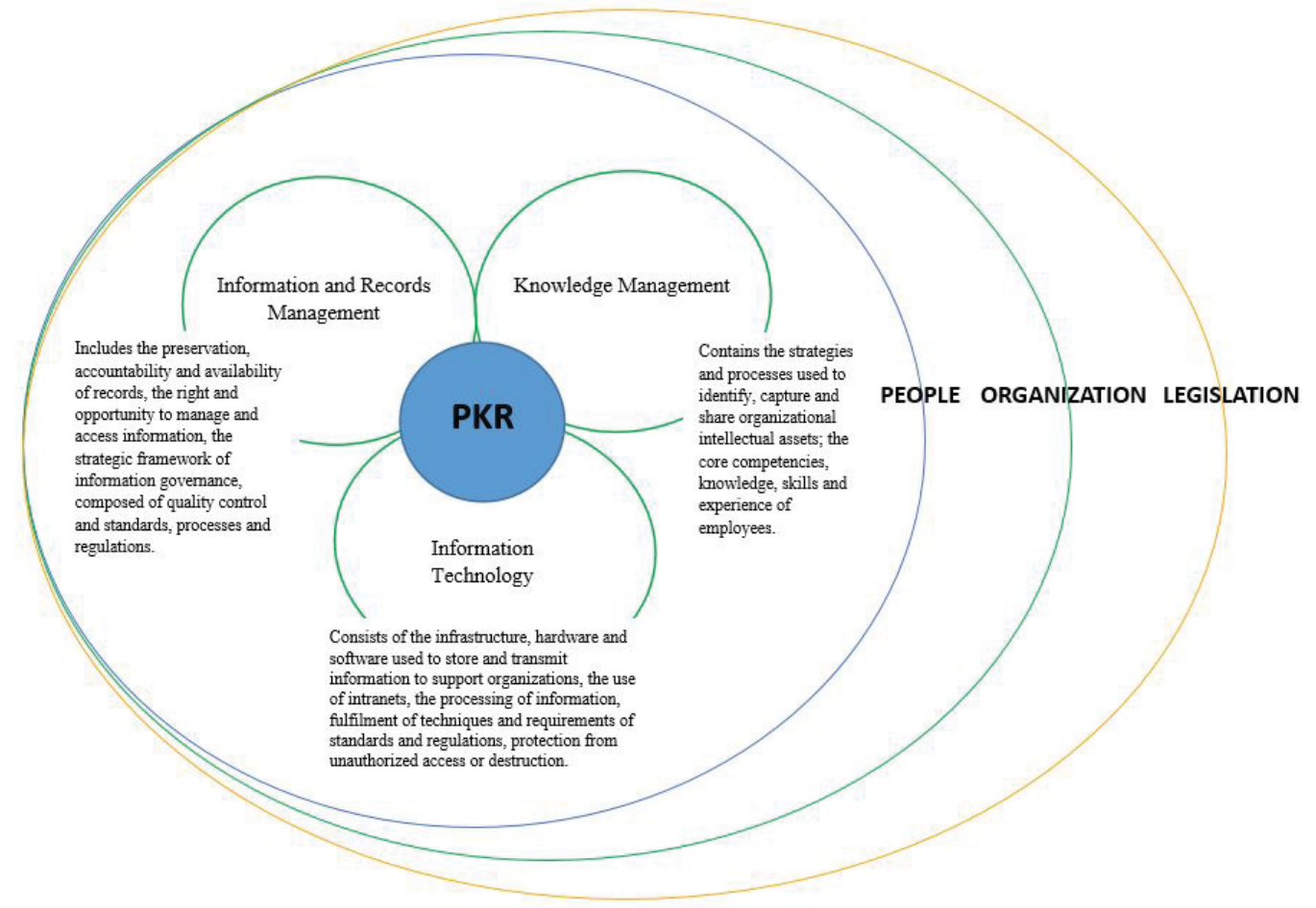

Figure 1: presents PKR amid KM, records and information management (RIM) and information technology (IT).

The figure also shortly labels the key contributions of each discipline. There are three circles; the innermost, blue circle signifies the people who are simultaneously users of, contributors to and objects of PKR. They represent the first internal factor of the model as key stakeholders as explained by Goldsmith et al. (2012). The green circle, titled organizations, presents the workplaces and the yellow circle the external framework in which the other two circles reside. KM, as presented in Figure 1, involves key factors of individual learning, i.e. the education, training and skills that the employee brings with him or her to the workplace and develops further, through adult-learning and webinars, while working. It also involves the social aspect of active participation, commitment and the willingness to share personal knowledge with co-workers (Fernie et al., 2003; Hwang, Lin and Shin, 2018).

While IT systems, as presented in Figure 1, consist of software, hardware, processes and policies that are used to organize, track and distribute information, whether placed in HRMS, intranet or a corporate social media platform, RIM includes a variety of processes, regulations and standards that hold organizations accountable for the right treatment of information assets (ARMA, 2016; McLeod, 2012b). The design, development and implementation of IT systems as well as its perceived user-friendliness by the users, affects the possible collaborative utility of the systems (Damodaran and Olphert, 2000; Bailey and Vidyarthi, 2010; Leyer, Schneider and Claus, 2016). Studies indicate that by using KMS organizations enable their employees to store the knowledge they "carry in their minds and make it available for wider use" (Sutanto and Jiang, 2013, p. 258). Knowledge sharing practices of this kind have been difficult to facilitate due to the sticky nature of knowledge and the great deal of effort needed for it to transfer (Szulanski, 2003; Leonardi and Meyer, 2015). This part of KM has been described as the "less tangible phenomena" as it usually concerns tacit knowledge which is related to the "expertise and experience" of employees (Choo et al, 2006, p.493).

\section{Knowledge Company of the Year - rhetoric or reality}

Ceremonial criteria of worth are useful, they legitimate organizations internally, with stockholders, the public, the state and they demonstrate socially the fitness of an organization (Meyer and Rowen, 1977, p. 351). Financial rewards, promotion and improved self-image tend to have a positive impact on organizations (Kankanhalli, Lee and Lim, 2011). Thus, management techniques, such as in the management of knowledge, must appear "progressive and accepted as the most efficient means to important ends" and at the forefront of management progress (Abrahamson, 1996). The Knowledge Company of the Year award stems from the year 2000. It is rewarded annually by the Icelandic Association of Economists and Business Graduates and is presented by the 
President of Iceland $\left(\mathrm{FVH}^{1}\right.$, 2019). The award only covers private organizations. Organizations are nominated by the members of the association according to an official theme of each year. Examples of such themes are: tourism, digital solutions, sustainable production and human resource management. Top three nominees are asked to deliver detailed information about their knowledge processes. Finally, an annual committee of KM specialists within the chosen theme, from the academia and from various business sectors, select the awardwinner. The award was originally portrayed as a means for organizations in Iceland to develop methods to effectively and successfully create, sustain, collect, share and use available knowledge and skills (Oladottir, 2001). These methods include learning processes empowered by KM. The success of the award-winners is defined in the way they make use of their collective knowledge in order to seize arising opportunities and resolve occurring operational difficulties in accordance to the annual theme.

Meyer and Rowen (1977) stated that there was a sharp distinction between formal structure of an organization and its actual day-to-day work activities. That organizations did not necessarily function in accordance with their formal blueprints, decisions might not be implemented, technologies might be inefficient and inspection systems too vague. An IT fashion, for example, is the collective belief that a certain information technology is the newest and at the forefront of practice. Early tools, used to create repositories of explicit knowledge to be shared ultimately evolved into "information graveyards" with few users and contributors (Barley, Treem and Kuhn, 2018). The findings of a recent case-study on two organizations described as "prominent in innovations and innovation activity" furthermore demonstrated that the organizations only loosely organized the storage and documentation of their knowledge and a formal strategy of data and information preservation was lacking (Grimsdottir and Edvardsson, 2018, p. 5). Former studies have also indicated that utility and usability in IT systems act as critical success factors and main causes of underutilization (Damodaran and Olphart, 2000; Leyer, Schneider and Claus, 2016). These beliefs support that following a fashion, such as trending IT, can legitimize organizations and their leaders regardless of performance improvement (Wang, 2010). PKR may turn out to be just another management fashion rather than an instrumental KM tool. Thus, organizations may appear rational after having completed an implementation of the latest fashion. Similarly, some might believe that knowledge award-winning organizations manage knowledge in a certain way, without knowing exactly what they do (Haraldsdottir, 2019). A respectable status of an organization such as a knowledge award may, therefore, legitimize an organization, regardless of the reality of their KM processes.

\section{Methodology}

The aim of this paper was to examine how knowledge award-winning organizations distinguished themselves from other organizations, when it came to the registration, access and use of the knowledge of employees. Whether the organizations benefitted financially from the registration process was also examined. Qualitative methodology was chosen for this research (Silverman, 2013; Gorman and Clayton, 2005). The reason for choosing a qualitative methodology was to shed a holistic light on the employees' experiences of the PKR methods that were applied in the organizations and to get a glimpse of their possible pitfalls and successes.

The data collection took place in Iceland. This is a multiple case study (Creswell, 2013; Merriam, 2009) containing 18 organizations. The organizations operated in different business sectors such as energy, engineering, finance, IT, manufacturing, telecommunication and tourism. The number of employees ranged from 50 to 2000 , with an average of 445 . Data gathering was conducted in three phases. The first phase was when organizations $A, B$ and $C$ were visited, and the scope of the research was established. Then, nine further organizations and an examination of organizational documentary material was accomplished. Interviews and gathering of documentary material from award-winning organizations M-S took place in 2017 and 2018. See table 1 for an overview.

\footnotetext{
${ }^{1}$ https://www.fvh.is is the website for the Association of Economists and Business Graduates and is only available in Icelandic.
} 
Table 1: Overview of the organizations

\begin{tabular}{|c|c|c|c|c|c|c|}
\hline $\begin{array}{l}\text { In-depth analysis in } \\
\text { the first group of six } \\
\text { organizations. 6-8 } \\
\text { intervievs in each } \\
\text { organization. }\end{array}$ & $\begin{array}{l}\text { A } \\
\text { Financial } \\
\text { Private } \\
\text { Nearly } 1000 \\
\text { employees. }\end{array}$ & $\begin{array}{l}\text { B } \\
\text { Technology } \\
\text { Private } \\
\text { Over } 500 \\
\text { employees. }\end{array}$ & $\begin{array}{l}\text { C } \\
\text { Industrial/Consultancy } \\
\text { Private } \\
300 \text { employees }\end{array}$ & $\begin{array}{l}\text { D } \\
\text { Industrial/energy } \\
\text { Public } \\
\text { Over } 250 \text { employees. }\end{array}$ & $\begin{array}{l}\text { E } \\
\text { Financial } \\
\text { Public } \\
\text { Nearly } 200 \\
\text { employees. }\end{array}$ & $\begin{array}{l}\text { F } \\
\text { Surveillance } \\
\text { Public } \\
\text { Almost } 240 \\
\text { employees. }\end{array}$ \\
\hline $\begin{array}{l}\text { First corroborative } \\
\text { interview group. One } \\
\text { interview in each } \\
\text { organization. }\end{array}$ & $\begin{array}{l}\text { G } \\
\text { Technology } \\
\text { Private } \\
\text { About } 600 \\
\text { employees. }\end{array}$ & $\begin{array}{l}\text { H } \\
\text { E-commerce } \\
\text { Private } \\
\text { Around } 270 \\
\text { employees. }\end{array}$ & $\begin{array}{l}\text { I Industrial/Consultancy } \\
\text { Private } \\
\text { About } 350 \text { employees. }\end{array}$ & $\begin{array}{l}\text { J } \\
\text { Surveillance } \\
\text { Public } \\
\text { Over } 150 \text { employees. }\end{array}$ & $\begin{array}{l}\text { K } \\
\text { Industrial/energy } \\
\text { Public } \\
\text { Around } 460 \\
\text { employees. }\end{array}$ & $\begin{array}{l}\text { L } \\
\text { Industrial } \\
\text { Public } \\
\text { Just over } 50 \\
\text { employees. }\end{array}$ \\
\hline $\begin{array}{l}\text { Second corroborative } \\
\text { interview group. } \\
\text { Award winners of the } \\
\text { Knowledge Company } \\
\text { of the Year Award. } \\
\text { One interview in each } \\
\text { organization. }\end{array}$ & $\begin{array}{l}\text { M } \\
\text { Private }\end{array}$ & $\begin{array}{l}\mathrm{N} \\
\text { Private }\end{array}$ & $\begin{array}{l}0 \\
\text { Private }\end{array}$ & $\begin{array}{l}\text { P } \\
\text { Private }\end{array}$ & $\begin{array}{l}R \\
\text { Private }\end{array}$ & $\begin{array}{l}\text { S } \\
\text { Private }\end{array}$ \\
\hline
\end{tabular}

The first six organizations were selected using purposive sampling based on the objective of the study (Esterberg, 2002). Prior to the interviews, existing organizational strategies on HR and/or training, as well as organizational websites, were studied. The first corroborative group (G-L) was selected using a snowball sampling (Neuman, 2006) as numerous interviewees from organizations A-F stated that organization G-L were more prominent regarding PKR. The main characteristic of the second corroborative group (M-S) was that they were all recipients of the Knowledge Company of the Year award and were, for that reason, considered likely to provide a different angle on the research topic. The focus was on examining the knowledge award verdicts for each award-winning organization and finding out in what manner these organizations were fulfilling their potential. In an invitation letter the research was briefly explained along with the decision to include the award winners.

\subsection{Semi-structured interviews}

Primary data was collected through semi-structured interviews. The interviewees were selected in a systematic manner and consisted of employees with similar positions in each organization. The purpose was to capture the perspectives of the interviewees and to examine how their experiences and meanings would explain the study (Yin, 2014). The intention was to compare the knowledge award-winning organizations to other organizations in terms of their PKR processes. A total of 35 interviews were conducted. An interview guide (Appendix A) was written. It was developed throughout the study using iterative updates based on additional information arising from the data (Bogdan and Biklen, 2003). First, an analysis of multiple interviews in organizations A-F and then corroborative analysis in organizations $G-L$ with one single interview in each organization. A single interview was conducted in organizations $\mathrm{M}-\mathrm{S}$, except in organization $\mathrm{O}$ where the HR manager and the training manager jointly took part in the interview.

The risk of revealing interviewees identities was significant, in particular in the case of the award-winners (Esterberg, 2002). Those had all been publicly associated with the award in the media and elsewhere. Sensitive information could be revealed and therefore appropriate to cover the names of individuals and organizations in all cases and the individual business sector of the award-winners.

\subsection{Discourse analysis}

The analysis of the documentary material was interlinked with the analysis of the interviews. The purpose of discourse analysis was to interpret the text at hand, and to better ensure the validity and reliability of the findings (Golafshani, 2003). Discourse analysis requires that documents are examined and interpreted in order to elicit meaning, gain understanding, and develop empirical knowledge (Corbin and Strauss, 2008; Gee, 2014). To better understand how PKR works, verdicts from the Knowledge Company of the Year award were examined. Internal documentary material and information available on organizational websites were examined as supportive material (Gee, 2014). The empirical analysis consisted of systematically reading the verdicts by studying the selection of words, repetitions and use of terms regarding knowledge, knowledge management, 
knowledge sharing, training, education, responsibility, collaboration, registration, access, use or reuse, or actual lack of these terms.

\section{Findings}

This section presents the analysis of the verdicts for the Knowledge Company of the Year award and the interviews. The verdicts were first studied and subsequently the perceptions of the interviewees on how PKR was facilitated and used in the award-winning organizations in comparison to other organizations. The same comparison was made on the interviewees' perceptions of possible financial benefits of PKR.

\subsection{Evaluation and verdicts of the knowledge award}

Table 2: Shows the six award-winning verdicts

\begin{tabular}{|c|c|c|c|c|c|}
\hline $\begin{array}{l}\text { M } \\
\text { The } \\
\text { organization } \\
\text { is being } \\
\text { awarded for } \\
\text { human } \\
\text { resources in } \\
\text { a broad } \\
\text { sense. As } \\
\text { described in } \\
\text { the jury's } \\
\text { results; the } \\
\text { organization } \\
\text { has a solid } \\
\text { education } \\
\text { and training } \\
\text { programme } \\
\text { for their } \\
\text { employees } \\
\text { and has been } \\
\text { a pioneer with } \\
\text { certain } \\
\text { programmes } \\
\text { which has } \\
\text { been a great } \\
\text { success. They } \\
\text { have also } \\
\text { succeeded in } \\
\text { creating job } \\
\text { security in the } \\
\text { organization } \\
\text { in a short time } \\
\text { after the } \\
\text { financial } \\
\text { crises in } \\
2008 .\end{array}$ & $\begin{array}{l}\text { N } \\
\text { The organization } \\
\text { has gained } \\
\text { noteworthy } \\
\text { success in its } \\
\text { operations and } \\
\text { increased their } \\
\text { productivity and } \\
\text { efficiency by } \\
\text { implementing } \\
\text { and developing } \\
\text { digital } \\
\text { solutions. This } \\
\text { implementation } \\
\text { has increased in } \\
\text { the efficiency of } \\
\text { their operations } \\
\text { and active } \\
\text { management of } \\
\text { their } \\
\text { organization, as } \\
\text { well as } \\
\text { optimized their } \\
\text { utilization in } \\
\text { proportion to the } \\
\text { more valuable } \\
\text { products. This } \\
\text { way, the } \\
\text { technology has } \\
\text { given the } \\
\text { organization the } \\
\text { possibility to } \\
\text { deliver their } \\
\text { production } \\
\text { process straight } \\
\text { into consumer } \\
\text { packages which } \\
\text { saves transport, } \\
\text { and transport } \\
\text { packaging, } \\
\text { which again is a } \\
\text { huge step to } \\
\text { decrease the } \\
\text { carbon } \\
\text { footprint. }\end{array}$ & $\begin{array}{l}\text { The organization } \\
\text { is exemplary in } \\
\text { good } \\
\text { governance and } \\
\text { has, for } \\
\text { example, } \\
\text { received the } \\
\text { Equal Pay } \\
\text { certificate from } \\
\text { VR [the Union of } \\
\text { Office and } \\
\text { Commercial } \\
\text { Employees] last } \\
\text { year as they } \\
\text { work on } \\
\text { balancing } \\
\text { gender ratio in } \\
\text { the workplace. } \\
\text { They monitor } \\
\text { job satisfaction } \\
\text { four times a year } \\
\text { by survey and } \\
\text { the results have } \\
\text { been positive. } \\
\text { Regarding social } \\
\text { responsibility } \\
\text { they have hired } \\
\text { a society } \\
\text { manager } \\
\text { working on } \\
\text { social matters. } \\
\text { Last year they } \\
\text { had 100 } \\
\text { projects } \\
\text { connected to } \\
\text { social } \\
\text { responsibility, } \\
\text { for example on } \\
\text { environmental } \\
\text { matters and } \\
\text { social matters. }\end{array}$ & \begin{tabular}{l}
\multicolumn{1}{c}{$P$} \\
The selection \\
was made with \\
consideration \\
to how future \\
vision, strategy \\
and values \\
mirror the \\
success that \\
the \\
organization \\
has gained in \\
recent years. \\
Social \\
responsibility \\
and good \\
governance \\
were also \\
considered. \\
Measurable \\
performance in \\
finance, \\
customer \\
satisfaction, \\
efficient inner \\
processes \\
and success \\
in human \\
resources \\
was also \\
evaluated.
\end{tabular} & $\begin{array}{l}\quad \text { R } \\
\text { It is a true } \\
\text { knowledge } \\
\text { organization } \\
\text { which is } \\
\text { exemplary in } \\
\text { most areas. } \\
\text { The diverse } \\
\text { origin of } \\
\text { employees has } \\
\text { been applied to } \\
\text { building up an } \\
\text { interesting } \\
\text { cultural unity } \\
\text { which } \\
\text { encompasses } \\
\text { the values and } \\
\text { objectives of } \\
\text { the } \\
\text { organization. At } \\
\text { the same time } \\
\text { the } \\
\text { organization } \\
\text { has created } \\
\text { itself a special } \\
\text { status on the } \\
\text { market, strong } \\
\text { brands and a } \\
\text { solid } \\
\text { knowledge } \\
\text { base. It is } \\
\text { seldom that } \\
\text { such an } \\
\text { organization } \\
\text { has such } \\
\text { strong } \\
\text { Icelandic roots } \\
\text { as evident in } \\
\text { this case. }\end{array}$ & $\begin{array}{l}\text { The } \\
\text { organization is a } \\
\text { pillar in the } \\
\text { Icelandic } \\
\text { labour market } \\
\text { which has } \\
\text { created great } \\
\text { value for the } \\
\text { country and the } \\
\text { nation. The } \\
\text { organization } \\
\text { has persisted } \\
\text { and delivered } \\
\text { real value for } \\
\text { the Icelandic } \\
\text { economy } \\
\text { despite } \\
\text { adversity. The } \\
\text { organization } \\
\text { has in the past } \\
\text { few years } \\
\text { implemented } \\
\text { large changes } \\
\text { and } \\
\text { adjustments } \\
\text { but } \\
\text { simultaneously } \\
\text { moved forward. }\end{array}$ \\
\hline
\end{tabular}

The terms "knowledge" or "knowledge sharing" was hardly mentioned in the six verdicts. Organization M was evaluated based on having "a solid education and training programme for their employees". The term "knowledge management" was not mentioned in the verdicts, but the "active management" of organization $\mathrm{N}$ was mentioned as it got more efficient due to the implementation of digital solutions. The value of human resources was portrayed in statements such as "being awarded for human resources in a broad sense" as in 
organization $\mathrm{M}$ and "efficient inner processes and success in human resources" as in organization $\mathrm{P}$. The term "responsibility" was mentioned twice in connection to "social responsibility" as in organization O where their responsible attitude towards various social and environmental matters was rewarded. Social responsibility and good governance were interconnected in the verdicts of both organization $\mathrm{O}$ and $\mathrm{P}$. Organization $\mathrm{P}$ was furthermore evaluated by their "measurable performance in customer satisfaction". Organization R was the only one described as a "true knowledge organization" as it was exemplary in most areas, including having "a solid knowledge base". The terms "training" or "education" were only mentioned once in the six verdicts. The term "collaboration" did not occur in the verdicts of the knowledge award-winners and neither did the term "registration", whether of intellectual assets, personal knowledge, valuable information or any other data. And finally, organization $\mathrm{S}$ was evaluated on the terms that it had delivered "real value for the Icelandic community" as a "pillar in the Icelandic labour market" despite adversity.

\subsection{Results from the interviews on PKR practices}

In a few non-winning organizations, such as: A, B, C, D, E and G, H, I and J certificates were collected from employees as a proof of necessary qualifications. To give some examples:

- The HR manager in organization A stated that they had not yet achieved their goal of covering all PKR but they were registering approximately $90 \%$ of their employees' formal education into their database.

- The HR manager in organization B maintained that PKR was of best use if it was available in a central database which was not entirely the case for them.

- Interviewees from the private organizations $\mathrm{G}, \mathrm{H}$ and I put much emphasis on gathering information regarding formal and informal education and experience of the employees and much effort was put into PKR.

- The HR manager in organization I maintained that it had taken "blood, sweat and tears" to register everything into the system, but as employees' knowledge was the most important sales product of the organization, it was of great significance.

- The training manager in organization $\mathrm{G}$ stated that the registrations were of utmost importance as their database of certified education and training of employees was directly interconnected to lowering their operational costs.

Still, organizations F, K and L, all public, were not as successful with PKR as other non award-winning organizations and had a limited overview. Their PKR consisted primarily of certificates on paper or scattered registrations in Excel spreadsheets. Still, PKR created value for most non-winning organizations as evidence for the benefit of the employees, organizational clients and to answer monitoring institutions. Thus, PKR provided valuables for most organizations as many clients expected them to demonstrate that they were qualified to undertake international assignments.

Similarly, the award-winners in organizations M-S stated that they were obligated to register certain education, training or knowledge of their employees.

- Knowledge registration is necessary due to compliance, said the HR manager in organization $\mathrm{M}$ as he described that there were certain requirements for certain jobs. "We are focusing on formal education" he said and was interested in seeing how many of their employees had a university degree, "we are now at 67\%". He was not on the opinion that his organization had managed to set up a perfect system as they were not registering other skills; "we are not there yet". He continued and said, "we may be overlooking someone who might be better, since we do not have this overview".

- The HR manager in organization $\mathrm{N}$ stated that they conducted an obligatory training programme for their employees. She said: "we must register their participation, also because participation is directly linked to the payroll and they get higher rate per hour."

- The HR manager and the training manager in organization $\mathrm{O}$ described their overview of personal knowledge; "it may be improved; registration and information of employees' knowledge was zero when we came". They said; "we are juggling this between us [...] to improve this foundation like the registration of knowledge". They had just begun using a new HR system and there was no added information registered, like language skills or other skills. They registered formal education and inhouse training, such as security and sanitation courses, which meant that they could provide a printout of employees' participation if needed. 
- Organization P was registering security, first aid courses and similar. The training manager claimed that the organization had "expanded faster than I don't know what" and that they had not managed to adjust properly to PKR. Employees' participation in in-house programmes were registered manually and external programmes that the employees attended were not registered at all.

- The local manager in organization R claimed that they were implementing a new global HR system into their organization, it included information on "your past, information on just your position in the organization, your team, which manager you belong to and your development here you know [..] and you know, education, courses and other things that you attend". She continued and explained that they needed to "eat the elephant one bite at the time" as that there was "room for improvement, especially in education and training".

- Organization S had built a knowledge centre with many classrooms in order to fulfil their training needs locally, to comply with rules, standards and regulations and safe costs. The HR manager said that they had developed a very functional system for those jobs that had to comply with certain international standards. They knew everything about the employees' experience and participation in training due to obligatory registrations, certifications and security prerequisites. As the job certificates of these employees was based on training the HR manager had no information whether these employees had different education as well, for example a university degree.

\subsection{Results from the interviews on the financial benefits of PKR}

When interviewees in the award-winning organizations were asked whether, and then how, they had experienced a financial gain in managing their intellectual assets using PKR, their answers were mostly positive:

- " "It's not visible in the income statement" said the HR manager in organization M, but "that's a norm for HR matters". PKR was a "nice-to-have" he said, but not a priority. Still, he found it important to measure how many employees had a university degree, which would give the organization certain credibility. He had decided to register and monitor the training of certain advisors, again for credibility reasons. Whether "it has a financial gain [he said laughing] I don't know, but hopefully better service".

- The interviewee in organization $\mathrm{N}$ claimed that the award was both a recognition of what they were doing and a motivation for further development in their field. She continued and said that the award had a clear marketing value for them "it is good externally, both the recognition and as an introduction of what we do".

- The interviewees in organization O claimed that by using PKR, one could set an objective [for recruitment or training for example] and measure hours of training, participation in training, and specific or necessary [obligatory] experience or expertise. By this means, they would know how far they had reached, for comparison and adjustments internally, but also for comparison with other organizations.

- The training manager in organization P was convinced that there was a financial and knowledgeable benefit in registering. She said that registration of employees' knowledge and training, gave people the opportunity to grow and by that, enhance their chance of long-term employment. Plus, through registration "you know what you lack and what you can do better".

- The local manager in organization R said that registering employees' personal knowledge was an investment. It is "really about having good overview of human resources, including their knowledge", she claimed. She stated that if one wants to develop knowledge, one must document it, it's not "at your fingertips" as people seem to think. Even though a knowledge directory "does not catch knowledge leakage" she said, we should register current knowledge into our systems, it's really "kind of a substitute strategy".

- The HR manager in organization S said that PKR had obvious benefits and saved time, "it's somehow so evident!". He said the purpose was to get better use of employees' knowledge which could also have impact on commitment and job satisfaction. He said: "It happens here like anywhere else that you might hire an external advisor at great expense, and then someone sits beside you [at work], that knows things even better." Still he compared PKR to a "two-edged sword" and said that they made sure to register obligatory training and expertise of certain staff members very carefully, but otherwise they did not put much effort into it. They were not willing to hire 2-3 employees to keep the directory up to date, he claimed.

In comparison, interviewees in organizations $A$ and $E$ were convinced that there was a financial gain in PKR. Money could be saved by having access to interactive databases for PKR with open access for all employees. In 
organization B an interviewee stated that it was necessary for management to calculate long term profit, instead of looking solemnly at the current financial status in the EBITDA. The HR manager in organization $\mathrm{C}$ said that they had spent money on external advisors and training, not knowing that the knowledge needed existed among their staff. In organization $\mathrm{E}$ an interviewee stated that it was timesaving to find necessary information on colleagues in a functional PKR database and, therefore, financially beneficial as well. Interviewees in organizations $\mathrm{J}, \mathrm{K}$ and $\mathrm{L}$ all claimed that there was a financial benefit in accumulating information into a database for PKR purposes. An interviewee in organization C claimed to have legitimate information which showed financial benefits. He stated it pointed to the lesser amount of time being spent on searching, which allowed more time to be spent with customers. The training manager in organization $\mathrm{G}$ claimed that certification of employees' qualifications was inextricably linked to lowering operational costs in his organization.

\section{Discussion}

The organizational context consisted of 18 organizations. Six of the organizations had received an award for outstanding success as the Knowledge Company of the Year for their best-practices of knowledge and thereby gained a ceremonial criterion of worth (Meyer and Rowen, 1977).

Many of the organizations were, at the time of the study, learning how to manage the knowledge embedded in their employees. This learning process applied to award-winning organizations in the same manner as other organizations which was perhaps not anticipated in the beginning of the research process. The award winners were considered more likely to be "pursuers of best practices ... and some of the most intellectually curious, performance-oriented organizations in [Iceland]", as once described by O'Dell and Grayson (1998, p. 155).

In short, the findings of this research support Davenport and Prusak's (1998) statement up to a certain point. The results indicated that the smaller organizations were better able to practise personal networking and communication than the larger ones. Then again, the findings indicated that, in organizations with as few as 50 employees, this reliable grasp was not enough to effectively access and use the knowledge of employees.

The award verdicts demonstrated considerable success in a wide area of best-practices of knowledge which confirms that knowledge is a key factor of production and competitiveness (Wasko and Faraj, 2005). Organization $\mathrm{M}$ was a pioneer in offering solid education and training programmes for employees while securing job security. Organization $\mathrm{N}$ had increased their productivity by implementing digital solutions, resulting in the optimization of knowledge use. Organization $\mathrm{O}$ was exemplary in social responsibility at the same time as job satisfaction was rising, and organization $\mathrm{P}$ was awarded for their measurable performance and successful inner processes. Organization R was described as a "true knowledge organization”, with its diverse origin of employees, cultural unity and solid knowledge base and organization $\mathrm{S}$ was rewarded for creating value for its country while facing adversity. Thus, these organizations were making use of their collective knowledge to seize arising opportunities and resolve occurring operational difficulties (Oladottir, 2001) as stated in the award criteria. Still, their success did not include an overall registration of employees' knowledge.

The term "registration" was not mentioned once in the verdicts, whether of intellectual assets, personal knowledge of employees or any other information. Three out of six award-winners claimed that they were possibly overseeing someone or had hired an external advisor at great expense as they lacked the overview of employees' knowledge as explained in Hesse (2017).

While most interviewees agreed that the financial benefits of PKR were considerable, some found PKR as just another intangible HR matter. Interviewees mostly agreed that the information registered in PKR was in fact not "at your fingertips" and that it was, therefore, necessary to have it registered which supports ARMA's argument on information assets (2016). These registrations were a part of a substitute strategy, they had evidential value and were positively connected to operational costs.

In the two organizations that experienced greatest success in PKR, organizations I and G, the registration, access and use of the knowledge of employees was primarily to have a comprehensive overview of their intellectual assets embedded in the employees, which resembles the results of Grimsdottir and Edvardsson (2018). It was considered of great importance to foresee which employees needed further training or could be involved in inhouse training. PKR was considered helpful to quickly respond to customers and send out proposals in different languages, which helped to fulfil customer demands and the organizations' competitiveness. The social 
significance of PKR and the collaborative aspect of the system was considered of great significance. It was the "nice-to-have" element of PKR. Employees were working collaboratively throughout the organization, cultivating a platform for personal interaction which relates to the results of Sigala and Chalkiti (2014).

Studies indicate that by using KM, organizations enable their employees to store the knowledge they "carry in their minds and make it available for wider use" (Sutanto and Jiang, 2013, p. 258). Still, all of the organizations, whether award-winners or not, were faced with challenges in the PKR process. In order to better understand these challenges a conceptual model was developed from a previous model (Haraldsdottir et al, 2018). See figure 2 .

Description of challenges

Facilitators of PKR

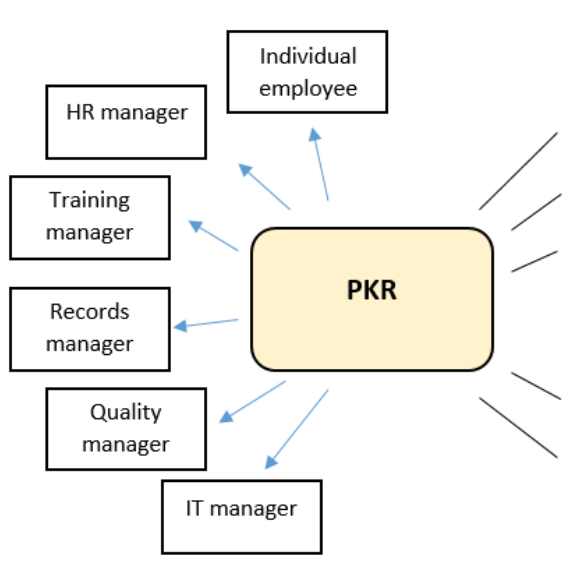

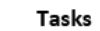

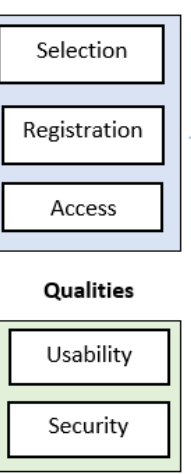

Selection takes time: What system to choose, needs-analysis, implementation, internal-marketing, moving towards an overal participation, selection of knowledge to register, interaction with employees of all (some?) levels, managerial support.

Registration is costly: The registration process, including; how to register, who is allowed to register (and what), what to register in PKR and what perhaps elsewhere, administration of registrations, maintenance of registrations, evaluation of the PKR system, inspection of registrations, system updates.

Access it limited: Who has access; to what sort of information, level of transparency, managerial decisions, often limited to the HR division, requirements of a google look-a-like system while employees' admittance is limited to their individual profile.

Usability is lacking: Access is limited and the usability of PKR therefore narrow. The registration of personal knowledge requires a purpose; unfulfilled user requirements, limited use is reflected in knowledge sharing and social networking.

Security is uncertain: GDPR is being implemented, fear of mistakes, uncertainty of individual rights versus legal obligations, fear of over-registration, tendency to postpone PKR until GDPR has been settled.

Figure 2: A conceptual model - description of PKR challenges

Different interviewees described how various tasks and qualities of PKR must cohere for an overall success. Collaborative use, the possibility to search for, find, and engage in personal interaction between the knowledge seeker with the knowledge owner, was only successful in two organizations. Collaborative selection of education and thereafter registration was in many cases not possible because of lack of access or because the PKR was only used randomly. The most plausible reason was, according to the results of the study, that employees lacked a clear purpose for their registration, i.e., their input into the system lacked a clear output for the benefit of the employee or the organization as claimed by Haraldsdottir et al., 2018.

The qualities of PKR introduced as access, usability and security were consequently challenged by this lack of registered knowledge. These qualities were characterized by hesitant actions and a lack of joint interpretation of the purpose of PKR which is reminiscent of the comparisons of early repositories with "information graveyards" in Barley, Treem and Kuhn (2018). This lack of purpose hindered the systems in becoming successful as collaborative directories of personal knowledge.

It has been widely accepted that the knowledge of employees is a dynamic source of competitive advantage for organizations (Buenechea-Elberdin, Sáenz and Kianto, 2018; Fernie et al., 2003; Hwang, Lin and Shin, 2018). This acceptance was first projected in the HR and training strategies which demonstrated great organizational interest in offering appropriate training programmes. Then, the same applied to the award verdicts. Those portrayed a positive picture of the outstanding success that the award-winning organizations had experienced due outstanding success in the use of knowledge.

The findings indicated, in the case of the knowledge-award winners, that the motivation for the registration of personal knowledge was restricted to compulsory or measurable registrations which resembles the studies of Meyer and Rowen (1977) on ceremonial criteria of worth. Examples of such registrations, obtained from the interviews, included the percentage of employees who had certain university degrees, using registration various 
statistics as a means to project credibility for clients, monitoring institutions or the community. Further registration of knowledge that could be called "nice-to-have" and considered useful for the workplace according to the interviewees, were not perceived as a registration priority. One possible reason for this perception was that they were simply "not there yet" or that their registrations were still only fragmented.

This study is not without limitations. First, the small size of the Icelandic community as the location in which this research took place provided a perhaps one-sided, all-Icelandic, picture of the current status of PKR. Again, as a large majority of the interviews and the documentary material was in Icelandic, some translation was necessary. The translator, in this case the researcher, made every effort to compare and combine the use of terms to make the translation as equivalent as possible to the original texts. Finally, this research is limited to the personal knowledge of employees registered into a directory at their own or their organizations' request. It is not a research that analyses knowledge management in general, including all the explicit organizational processes, best practices, tools and guidelines that may be registered in a repository of documents, records, forms, diagrams and processes situated in the various hardware and software within an organization.

Practical implications of this study could be aimed at inspiring organizations to communicate information on the knowledge of employees to augment the social interaction of employees. The insights into the PKR process showed that the registration of the personal knowledge of employees was lacking in most cases. It is probable that some PKR challenges may be easily reduced, such as by using a single information system for the registration of knowledge instead of many, with added support of top-management and, by defining where the responsibility of the registration process lies. Interestingly, the most fruitful examples of PKR use were discovered among non award-winning organizations. A deeper examination of the perspectives of top managers and other employees within those and other prosperous non award-winning organizations could advance the research topic. Positive PKR experience regarding the purpose, utility, transparency and value of the registration of knowledge could bring practical implications for organizations interested in implementing a social knowledge platform.

\section{Conclusion}

The organizations that had received a knowledge award were not necessarily better at PKR than the non-winning organizations. The findings showed that the organizations faced great challenges in their PKR processes and their efforts were, therefore, just another way of legitimizing the organizations and their leaders regardless of performance improvement. Still, it cannot be claimed that the award-winners were simply following a management fashion as described by Abrahamson (1996) as they were awarded for good reasons.

The findings also show that the insights into the PKR process, its pitfalls and successes, have practical implications for organizations to reflect over and better prepare for the implementation of PKR. In order to prevent PKR from becoming the latest fashion manoeuvre, organizations need to develop a collaborative understanding of the sort of information on the knowledge of employees, and how much of it, is to be registered and where. The most influential requirement for successful PKR was that the purpose of the PKR must be clear. Without a clear purpose PKR remains underutilized and lacking financial or social value for the organizations and their employees.

This research looks at a hitherto under-explored topic within KM. This research may be broadened to other countries to obtain a more international perspective and a more holistic comparison. A more detailed examination of the possible financial benefits of PKR use is also of interest. To see if PKR really brings valuable results in terms of better use of the personal knowledge of employees through a more structured overview. These two research avenues could be launched with a different framework of organizations consisting of organizations from certain industries, such as higher education or public administration.

Finally, and considering an apparent tendency to label the modern workplace as smart, the use of social media as a platform for PKR is an interested topic and was expected to be more noticeable in this study. Social media has become an influential proxy in our private lives as well as in our workplaces. Some might even claim that we are amid yet another social revolution, as the digital platform of social media has radically changed the way people interact and communicate. The use of social media in the workplace also poses new challenges, such as the risk of overuse, multitasking, changes in communication patterns, and the risk of weakening the importance of rich personal communication between co-workers. Social media has been described as more open, interactive, fluid and dynamic than other forms of virtual communities and is most commonly used for making 
connections. Since the results of this study did not support this notion, and the use of social media for PKR purposes was non-existent in the participating organizations, this topic is yet to be fully explored.

\section{References}

Abrahamson, E. 1996. Management Fashion. The academy of Management Review, 21(1), pp. 254-285.

ARMA International 2016. Glossary of records management and information governance terms. 5th ed. Overland Park: ARMA International.

Bailey, S. and Vidyarthi, J. 2010. Human-computer interaction: The missing piece of the records management puzzle? Records Management Journal, 20(3), pp. 279-290.

Barley, W. C., Treem, J. W. and Kuhn, T. 2018. Valuing multiple trajectories of knowledge: A critical review and agenda for knowledge management research. Academy of Management Annals, 12(1).

Bogdan, R. C., and Biklen, S. K. 2003. Qualitative research of education: an introductive to theories and methods. 4th ed. Boston: Allyn and Bacon.

Buenechea-Elberdin, M., Sáenz, J. and Kianto, A. 2018. Knowledge management strategies, intellectual capital, and innovation performance: a comparison between high- and low-tech firms. Journal of Knowledge Management, 22(8), pp. 1757-1781.

Choo, C. W., Furness, C., Paquette, S., Van Den Berg, H., Detlor, B., Bergeron, P. and Heaton, L. 2006. Working with information: information management and culture in a professional services organization. Journal of Information Science, 32(6), pp. 491-510.

Corbin, J. and Strauss, A. 2008. Basics of qualitative research, techniques and procedures for developing grounded theory. London: Sage Publications.

Creswell, J. W. 2007. Qualitative inquiry and research design: choosing among five traditions. Thousand Oaks: Sage Publications.

Christensen, P. H. and Pedersen, T. 2018. The dual influences of proximity on knowledge sharing. Journal of Knowledge Management, 22(8), pp. 1782-1802.

Damodaran, L., and Olphert, W. 2000. Barriers and facilitators to the use of knowledge management systems. Behaviour and Information Technology, 19(6), pp. 405-413.

Davenport, T. H. and Prusak, L. 1998. Working knowledge. Boston: Harvard Business School Press.

Evans, M. M., Frissen, I. and Choo, C. W. 2019. The Strength of Trust Over Ties: Investigating the Relationships between Trustworthiness and Tie-Strength in Effective Knowledge Sharing. The Electronic Journal of Knowledge Management 17(1), pp. 19-33.

Esterberg, K. G. 2002. Qualitative methods in social research. Boston: McGraw-Hill.

Fernie, S., Green, S. D., Weller, S. J. and Newcombe, R. 2003. Knowledge sharing: context, confusion and controversy. International Journal of Project Management, 21, pp. 177-187.

FVH, 2019. [Online] Available at: https://fvh.is/thekkingarverdlaun/ [Accessed 25. November 2019].

Gee, J. P. 2014. How to do discourse analysis: a toolkit. New York: Routledge.

Golafshani, N. 2003. Understanding reliability and validity in qualitative research. The Qualitative Report, 8(4), pp. 597606.

Goldsmith, P., Joseph, P. and Debowski, S. 2012. Designing an effective EDRMS based on alters service work system model. Records Management Journal, 22(3), pp. 152-169.

Gorman, G. E. and Clayton, P. 2005. Qualitative research for the information professional: a practical handbook. London: Facet Publishing.

Grimsdottir, E. and Edvardsson, I. R. 2018. Knowledge management, knowledge creation, and open innovation in Icelandic SMEs, Sage Open, Oct-Dec, pp. 1-13.

Haraldsdottir, R. K. and Gunnlaugsdottir, J. 2018. The missing link in information and records management: personal knowledge registration. Records Management Journal, 28(1), pp. 79-98.

Haraldsdottir, R. K., Gunnlaugsdottir, J., Hvannberg, E. and Christensen, P. H. 2018. Registration, access and use of personal knowledge in organizations. International Journal of Information Management, 40(1), pp. 8-16.

Haraldsdottir, R. K. 2019. Managing Personal Knowledge: Are Award-Winners Doing Better? Proceedings of the 20th European Conference on Knowledge Management. Lisbon. 5-6 September 2019. Reading: ACPI. pp. 480-488.

Hesse. J. 2017. Why companies need to build a skills inventory" Strategy+business, October 31. [Online]. https://www.strategy-business.com/blog/Why-Companies-Need-to-Build-a-Skills-Inventory?gko=8b016

Hwang, Y., Lin, H., and Shin, D. 2018. Knowledge system commitment and knowledge sharing intention: The role of personal information management motivation. International Journal of Information Management, 39, pp. 220-227. https://doi.org/10.1016/j.ijinfomgt.2017.12.009

Kankanhalli, A., Lee, O. and Lim, K. H. 2011. Knowledge reuse through electronic repositories: a study in the context of customer service support. Information and Management, 48(2-3), pp. 106-113.

Kavanagh, M. and Johnson, R. 2017. Human resource information systems. London: Sage Publications.

Leonardi, P. M. and Meyer, S. R. 2015. Social media as social lubricant: how ambient awareness eases knowledge transfer. American Behavioral Scientist, 59(1), pp. 10-34.

Leyer, M., Schneider, C., and Claus, N. 2016. Would you like to know who knows? connecting employees based on processoriented knowledge mapping. Decision Support Systems (87), pp. 94-104. 
McFarland, L. A. and Ployhart, R. E. 2015. Social media: a contextual framework to guide research and practice. Journal of Digital Psychology, 100(6), pp. 1653-1677.

McLeod, J. 2012. Thoughts on the opportunities for records professionals of the open access, open data agenda. Records Management Journal, 22(2), pp. 92-97. https://doi.org/10.1108/09565691211268711

Merriam, S. 2009. Qualitative research: a guide to design and implementation. San Francisco: John Wiley and Sons.

Meyer, J. W. and Rowen, B. 1977. Institutional organizations: formal structure as myth and ceremony. American Journal of Sociology, 83(2), pp. 340-363.

Neuman, W. L. 2011. Social Research Methods: Qualitative and Quantitative Approaches. New York: Pearson Education Limited.

O'Dell, C. and Grayson, C. J. 1998. If only we knew what we know. The transfer of internal knowledge and Best Practices. New York: The Free Press.

Oladottir, A. D. 2001. Knowledge and learning: the key to a successful and consistent competitive advantage? Reykjavik: University of Iceland.

Pauleen, D. 2009. Personal knowledge management: Putting the "person" back into the knowledge equation. Online Information Review, 33(2), pp. 221-224.

Sigala, M. and Chalkiti, K. 2014. Investigating the exploitation of web 2.0 for knowledge management in the Greek tourism industry: An utilisation-importance analysis. Computers in Human Behaviour, 30, pp. 800-812.

Silverman, D. 2013. Doing qualitative research. 4th ed. London: Sage Publications.

Sundquist, A. and Svärd, P. 2016. Information culture and records management: a suitable match? Conceptualizations of information culture and their applications on information management. International Journal of Information Management, 36(1), pp 9-15.

Sutanto, J. and Jiang, Q. 2013. Knowledge seekers' and contributors' reactions to recommendation mechanisms in knowledge management systems. Information and Management, 50(5), pp. 258-263.

Szulanski, G. 2003. Sticky knowledge, barriers to knowing in the firm. London: Sage Publications.

Wang, P. 2010. Chasing the hottest IT: effects of information technology fashion on organizations. MIS Quarterly, 34(1), pp. 63-85.

Wasko, M. M. and Faraj, S. 2005. Why should I share? examining social capital and knowledge contribution in electronic networks of practice. MIS Quarterly, 29(1), pp. 35-57.

Yin, R. K. 2014. Case study research: design and methods. Thousand Oaks: Sage Publications. 


\section{Appendix A - Interview guide}

Some thought prior to interview:

- In what manner do organizations support PKR?

- By what means does the registration of personal knowledge impact the work of different employees?

- What information on personal knowledge is registered?

- Who is responsible for the registration?

- In what way is the information that is already registered used as a basis for further needs-analysis (recruitement - training)?

- In what way (if any) is the success of personal knowledge registration evaluated (in the long run)? What ways are there to evaluate the registration?

- Is there a financial gain in personal knowledge registration? If so - how is it evaluated? Do the interviewees have any examples to support the argument?

- In what way (if any) is knowledge sharing made easier than before using registration for the knowledge of employees?

\section{Personal knowledge registration:}

- What is the current situation of personal knowledge registration in your organization?

- Do you have an electronic database of some sort for registering the formal education of employees?

- How is informal education (training, courses and so on) registered?

- Is the registration placed centrally (the HR department for example) or are employees registering themselves (everything, some parts - how?)

- What system(s) are you using to register the personal knowledge of employees?

- Who is in charge of the registration process?

- Are others involved? If so - how?

- What sort of filtering are you using in the registration process (open text or pre-defined lists of education)?

\section{Access and Use}

- Who has access to this information (education, training, skills)?

- If the access is limited - please explain (elaborate further) on terms of access

- In what way (if any) is this registration useful?

- For the employees?

- For the organization?

- For other purposes - which ones?

- Do you have the access that you need?

- If not - why?

- To what sort of information would you like to have access to (that you do not have now)?

- What is the purpose of the registration? (Please elaborate)

- In what manner is the registered information on the education, training and skills used in your work environment?

\section{Information systems:}

- In what manner is the information on employees formal and informal education and training registered?

- Who has access?

- How is this access controlled? How is it decided? If the access is limited - what are the reasons?

- In what manner (if any) are employees encouraged to share their personal knowledge with colleagues?

- What is (according to the organizational strategy (HR and training policy)) the aim of the organization in terms of knowledge sharing of employees? 